\title{
Diversity and Mealybug Transmissibility of Ampeloviruses in Pineapple
}

\author{
D. M. Sether, M. J. Melzer, and J. Busto, University of Hawaii at Manoa, Department of Plant and Environmental \\ Protection Sciences, Honolulu 96822; F. Zee, USDA-ARS National Clonal Germplasm Repository, Hilo, HI 96720; \\ and J. S. Hu, University of Hawaii at Manoa, Department of Plant and Environmental Protection Sciences, Honolulu \\ 96822-2232
}

\begin{abstract}
Sether, D. M., Melzer, M. J., Busto, J., Zee, F., and Hu, J. S. 2005. Diversity and mealybug transmissibility of ampeloviruses in pineapple. Plant Dis. 89:450-456.

Mealybug wilt of pineapple (MWP) is one of the most destructive diseases of pineapple (Ananas comosus) worldwide. At least one Ampelovirus species, Pineapple mealybug wilt associated virus-2 (PMWaV-2), and mealybug feeding are involved in the etiology of MWP. A previously undescribed Ampelovirus sharing highest homology with PMWaV-1 and a putative deletion mutant sharing highest homology with PMWaV-2 were detected with reverse transcriptionpolymerase chain reaction (RT-PCR) assays using degenerate primers. Results were verified with additional sequence information and by immunosorbent electron microscopy. Sequence homology between the virus tentatively designated PMWaV-3, and PMWaV-1 and PMWaV-2, decreases toward the N-terminal across the HSP70 homolog, small hydrophobic protein, and RNA-dependent RNA polymerase open reading frames (ORF). Putative PMWaV-3 could not be detected with four different monoclonal antibodies specific for PMWaV-1 and PMWaV-2. The potential deletion mutant spanning the N-terminal of the HSP70 region was obtained from a pineapple accession from Zaire maintained at the USDA-ARS National Clonal Germplasm Repository in Hawaii. Putative PMWaV-3, like PMWaV-1 and PMWaV-2, is transmissible separately or in combination with other PMWaVs by Dysmicoccus brevipes and D. neobrevipes mealybugs. Plants infected with PMWaV-3 that were continuously exposed to mealybugs did not develop symptoms of MWP in the absence of PMWaV-2. Specific RT-PCR assays were developed for detection of putative PMWaV-3 and the deletion mutant.
\end{abstract}

Additional keywords: vector transmission

One of the most devastating diseases of pineapple, Ananas comosus (L.) Merr., worldwide is mealybug wilt of pineapple (MWP) $(1-3,18)$. The etiology of MWP was recently shown to involve an $\mathrm{Am}$ pelovirus species and mealybug feeding $(7,21,22,24,25)$. Two ampeloviruses, Pineapple mealybug wilt associated virus-1 (PMWaV-1) and PMWaV-2 have been identified in pineapple grown in Hawaii $(4,6,9,15,26)$. Pineapple plants that were PMWaV-free or infected with PMWaV-1, PMWaV-2, or both viruses did not express symptoms of MWP if maintained mealybug-free $(21,22,24,25)$. MWP symptoms were also not induced by mealybug feeding if plants were PMWaV-free or infected with only PMWaV-1 $(24,25)$ Mealybug exposure and the presence of PMWaV-2 infection, however, resulted in the induction of MWP symptoms (24). Genomic analyses of PMWaV-1 (M. J. Melzer, D. M. Sether, A. V. Karasev, and J. S. Hu,

Corresponding author: J. S. Hu

E-mail: johnhu@hawaii.edu

Accepted for publication 8 December 2004.

DOI: 10.1094/PD-89-0450

(C) 2005 The American Phytopathological Society unpublished) and PMWaV-2 (15) have shown that the two viruses are distinct rather than serotypes or strains of similar viruses. Tissue blot immunoassays (TBIA) using specific monoclonal antibodies (MAbs) produced for PMWaV-1 (8) and PMWaV-2 (24) have detected these viruses in healthy-appearing and mealybug wiltsymptomatic pineapple from most of the major pineapple production areas of the world and in pineapple accessions maintained at the USDA-ARS National Clonal Germplasm Repository (NCGR) in Hilo, HI $(8,26)$. In Hawaii, the incidence of PMWaV1 in healthy-appearing pineapple ranges from 0 to $100 \%$ (8), whereas the incidence of PMWaV-2 ranges from 0 to $20 \%$ (26) depending on proprietary pineapple cultivar or hybrid. PMWaV-1 and PMWaV-2 infections in the absence of MWP correlate with reduced fruit yield in the ratoon crop, which manifests as a reduction of suckers or ratoons and a shift to smaller commercial fruit size categories $(23,25,28)$. These two PMWaVs are transmitted by two pineapple mealybugs, the pink, Dysmicoccus brevipes (Cockerell), and gray, D. neobrevipes (Beardsley), (21,22,24,25,27) and are members of the Ampelovirus genus in the family Closteroviridae (13).

Pineapple is typically propagated by crowns produced above the fruit, slips produced on the petiole below the fruit, suckers produced at the stem (11), or meristems in tissue culture. Crowns and slips arising from healthy-appearing PMWaVinfected plants are also symptomless (26); thus, infected planting material is commonly used to establish the plant crop, which requires 18 to 20 months until fruit harvest. Following the plant crop, a ratoon crop arises from one or more suckers produced by the senescing crop plants. Fruit from the first ratoon crop is typically harvested in 13 to 15 months (16). Presently, additional ratoon crops are rare in Hawaii. Increased incidence of MWP, nematodes, Phytophthora sp., bacterial diseases, and accompanying reduced fruit yield render crops beyond the first ratoon uneconomical $(17,18)$. The two ampeloviruses previously identified in pineapple significantly contribute to this profit reduction because of the involvement of PMWaV-2 in the etiology of MWP, which can cause up to a $100 \%$ fruit loss (25) and because of the 5 to $15 \%$ ratoon crop yield reduction associated with PMWaV infection $(23,25,28)$. Thus, the identification and use of PMWaV-free planting material and the prevention of new PMWaV infections could have significant economic benefits.

Genetically distinct virus isolates have been identified within the citrus tristeza $(5,14)$, lettuce infectious yellows $(19,20)$, and grapevine leafroll $(12,30)$ disease complexes in the family Closteroviridae. Such diversity possibly arises from the absence of template proofreading in RNA viruses that rely on RNA-dependent RNA polymerases (RdRp) for replication, or through recombination (10). As genetic similarity decreases, independent origin of the viruses may be suggested. Little cherry virus-1 (LChV-1) and LChV-2, which are now considered to be different genera, and possibly PMWaV-1 and PMWaV-2 may be examples of viruses having distinct origins. Virus isolates within each of these disease complexes can differ in the type of symptoms induced, severity of disease, and vector transmissibility. We hypothesize that additional diversity also occurs in the PMWaV complex. Identification of additional PMWaVs and the development of reliable detection assays for such viral variants would assist in the identification of PMWaV-free material for planting and germ plasm maintenance. We analyzed 38 pineapple accessions maintained at the 
USDA-ARS NCGR in Hilo, with reverse transcription-polymerase chain reaction (RT-PCR) assays using degenerate primers based on conserved sequences within the HSP70 homolog gene of several closteroviruses. Virus variants were sequenced, and specific RT-PCR detection assays were developed and used to assess virus incidence in over 250 commercial, field-grown pineapple plants from six Hawaiian proprietary selections of 'Smooth Cayenne' and six hybrids, including a hybrid recently introduced into Hawaii from two different countries. A putative new PMWaV was also subjected to serological, biological, and vector transmissibility tests.

\section{MATERIALS AND METHODS}

Virus sources and RNA isolation. Leaf samples were obtained from pineapple accessions maintained at the USDA-ARS NCGR in Hilo. Leaf samples were also collected from 20 or 25 randomly selected plants growing in a plantation field block composed of one type of hybrid or cultivar selection, respectively. Five field blocks from each cultivar and hybrid available for evaluation on Oahu and Maui were sampled. Samples were processed within $16 \mathrm{~h}$ of collection. RNA was isolated from the leaf samples using RNeasy Plant Mini Kits (Qiagen, Valencia, CA) with the following adaptations. The basal white portion of a leaf was powdered in liquid nitrogen with mortar and pestle. Frozen tissue $(100 \mathrm{mg})$ was transferred to a liquid nitrogen chilled, siliconized microfuge tube. GLC Buffer (450 $\mu \mathrm{l})$ with $0.1 \%$ 2-mercaptoethanol was added to the tube and vortexed for up to 1 min or until the mixture was thawed. The tube was briefly spun to collect plant matter before transfer to a QiaShredder column. Thereafter, RNA extraction was performed as outlined by the manufacturer's instructions. RNA was stored at $-80^{\circ} \mathrm{C}$ until needed. Double-stranded RNA (dsRNA) was isolated from pineapple tissue infected with either PMWaV-1, PMWaV-2, or PMWaV-3, as previously described (6). DsRNA samples were run in $1 \%$ agarose gel with ethidium bromide, and high-molecular-weight bands were extracted from the gel and stored at $-20^{\circ} \mathrm{C}$ until needed for cDNA synthesis.

RT-PCR, sequencing, and genomic walking. Pineapple accessions maintained at the USDA-ARS NCGR were initially screened with PMWaV-1- and PMWaV-2specific MAbs in TBIA as previously described $(9,24)$. Degenerate sense and antisense primers 249 (5'-GGARGTNGG NWWHGAMTTYGGNACNAC-3') and 250 (5'-GANVHRTCRAAMGTSCCTCCN CCRAARTC-3'), respectively, were developed based on conserved regions within the HSP70 homolog genes of PMWaV-1 (M. J. Melzer, D. M. Sether, A. Karasev, and J. S. Hu, unpublished), PMWaV-2 (15), and Grapevine leafroll associated virus-3 (12). RNA from selected plants found free of PMWaV-1 and PMWaV-2 in TBIA were subjected to RT-PCR using primers 249 and 250 under the reaction conditions previously described (26). RTPCR reactions were visualized in $1 \%$ agarose gels stained with ethidium bromide. Amplicons were purified from the gel and cloned into pGEM-T easy vector (Promega, Madison, WI). Plasmids were purified using QIAprep Spin Mini-prep plasmid DNA extraction kits (Qiagen) and sequenced with T7 and SP6 primers in an automated sequencer Model ABI373 or ABI377 at the Biotechnology/Molecular Biology Instrumentation and Training Facility, University of Hawaii, Honolulu. Sequence data were analyzed using the web-based GCG package SeqWeb 1.1 (Genetics Computer Group, University of Wisconsin, Madison). Basic Local Alignment Search Tool algorithm (BLASTX) was used to translate nucleotide sequences to amino acid sequences and to compare putative translation products with sequences in the National Center for Biotechnology Information website (NCBI). Amino acid identity and similarity was computed with the BLOSUM62 matrix. Specific sense and antisense primers 264 (5'-AGTTCACTGTAGATTTCGGA-3') and 263 (5'-ATTGATGGATGTGTATCG-3') for putative PMWaV-3 were developed and used in conjunction with primer set 225 (5'ACAGGAAGGACAACACTCAC- $3^{\prime}$ ) and 226 (5'-CGCACAAACTTCAAGCAATC$3^{\prime}$ ) for PMWaV-1 (26), and set 224 (5'CATACGAACTAGACTCATACG- ${ }^{\prime}$ ) and 223 (5'-CCATCCACCAATTTTACTAC$3^{\prime}$ ) for PMWaV-2 (24) in RT-PCR assays to determine the distribution of PMWaV-1, PMWaV-2, putative PMWaV-3, and a potential deletion mutant in USDA-ARS maintained pineapple accessions and commercially grown pineapple cultivars and hybrids in Hawaii. Due to the proprietary nature of the commercial pineapple cultivars and hybrids, they are identified by numbers consistent with previous reports (26). DsRNA from a plant that was RTPCR positive for PMWaV-3 was heat denatured, and first-strand cDNAs were synthesized at $37^{\circ} \mathrm{C}$ using Superscript II reverse transcriptase (Life Technologies, Grand Island, NY) with a specific antisense primer for PMWaV-3 following the manufacturer's instructions. Step-by-step walking procedures were performed with the first-strand mixture and PCR to clone the region upstream of the $h s p 70$ domains as previously described (15). Briefly, cDNA first-strand mixture was added to approximately 20 PCR reactions, each containing a different random primer and a specific PMWaV-3 primer. The amplification protocol consisted of one cycle at $94^{\circ} \mathrm{C}$ for 4 min, 45 cycles of $94^{\circ} \mathrm{C}$ for $1 \mathrm{~min}, 33^{\circ} \mathrm{C}$ for $1 \mathrm{~min}, 72^{\circ} \mathrm{C}$ for $2 \mathrm{~min}$, and a final elongation period of $10 \mathrm{~min}$ at $72^{\circ} \mathrm{C}$.

Mealybug transmissibility and induction of MWP. Leaves from USDA-ARS
NCGR pineapple accessions 100, 111, and 126 that were PMWaV-3 infected and a PMWaV-free plant from selection 1 were used for PMWaV acquisition sources by $D$. brevipes and $D$. neobrevipes as previously described $(25,27)$ with the following modification. Mealybugs (20 to 40 mixed-aged instars) were allowed to acquire from the white portions of individual virus-infected leaves for $48 \mathrm{~h}$. Insects were transferred while actively feeding on the declining leaf tissue to the test plants. Voucher specimens of the two mealybug species were made as previously described (29). Transmission and symptom induction experiments with each species of mealybug allowed to acquire from accessions 100, 111, and 126 were conducted simultaneously from May 2003 to January 2004 but at different locations on the island of Oahu to prevent mixing of the mealybug species. Transmission experiments with hybrid 9 plant material as an acquisition source for PMWaV-3 were conducted only during the summer to winter months from June 2003 to January 2004. Plants from Smooth Cayenne cultivar selection 2 and hybrid 5 were used for inoculation access (IA) for 20 to 40 mealybugs per plant approximately 2 months after rooting of crowns. All plants were tested with specific TBIA and RT-PCR assays twice prior to mealybug exposure to ensure absence of PMWaV-1, -2 , and -3 . Five plants from each cultivar selection were used for IA from each acquisition source. Nonviruliferous pink or gray pineapple mealybugs (40 to 60 mixed-aged instars) were added to plants in the transmission trials at weekly intervals to maintain the presence of the same mealybug species used for IA on these plants (24). Supplemental mealybug inoculations are generally required to sustain mealybug presence on the pineapple plants in the absence of attending ants. One month postinoculation exposure, plants were moved from a glasshouse to an outdoor location. Plants were tested for PMWaVs with specific RT-PCR assays beginning 2 months after initial exposure to mealybugs.

Virus purification and serological analyses. Infected plants were identified with PMWaV-specific RT-PCR assays (26), and virus particles were purified as previously described $(9,25)$. PMWaV-1specific MAbs 35-6-5 and 63-1-2 (9) and PMWaV-2-specific MAbs 63-2-2 $(25,26)$ and 30 (D. M. Sether and J. S. Hu, unpublished), were used in TBIA and immunosorbent electron microscopy (ISEM) to determine antigenicity between the MAbs and the different PMWaVs as previously described $(8,25)$.

\section{RESULTS}

RT-PCR using degenerate primers targeting the $\mathrm{A}$ and $\mathrm{E}$ conserved motifs within the HSP70 homolog region of the closteroviruses PMWaV-1, PMWaV-2, and 
GLRaV-3 amplified a weak but discrete 600-bp band from pineapple accession no. 30 of the USDA-NCGR collection. This accession, named 'Sylhet Jaldubi', originated from the Philippines. The amplicon shared the highest amino acid sequence homology to nucleotides 10 to 607 of the HSP70 homolog region of PMWaV-1. Overlapping clones spanning a consecutive region upstream of the HSP70-like region were generated using cDNA templates derived from dsRNA isolated from pineapple accession 30 and a walking strategy. Amino acid identities and similarities of the 1,271-bp partial sequence spanning the C-terminal end of an RNA-dependent RNA polymerase open reading frame (ORF), a gene encoding a small hydrophobic protein with a predicted molecular mass of 5,650 Da, and the N-terminal end of the HSP70 ORF show that this putative virus, tentatively designated PMWaV-3, is more closely related to PMWaV-1 than to PMWaV-2 and other Closteroviridae members (Table 1). Amino acid similarities between PMWaV-3 and PMWaV-1 for the $\operatorname{RdRp}(70.6 \%)$, small hydrophobic protein $(82.4 \%)$, and HSP70 (84.7\%) regions increase toward the C-terminal of the putatively distinct virus. Amino acid similarities between PMWaV-3 and GLRaV-4, GLRaV-5, GLRaV-6, and GLRaV-9 for the $\mathrm{N}$-terminal end of the HSP70 ORF ranged from 73.0 to $75.1 \%$, whereas similarity between PMWaV-3 and PMWaV-2 across the same region was only $51.0 \%$.

Specific RT-PCR assays and virus incidence. Oligonucleotides 263 and 264

Table 1. Percentage of amino acid identity and similarity shown in parentheses shared between putative Pineapple mealybug wilt associated virus-3 (PMWaV-3) and other ampeloviruses and members of the family Closteroviridae across three open reading frames

\begin{tabular}{|c|c|c|c|c|}
\hline \multirow[b]{2}{*}{ Virus $^{a}$} & \multirow{2}{*}{$\begin{array}{l}\text { GenBank } \\
\text { accession }\end{array}$} & \multirow[b]{2}{*}{ RdRp } & \multicolumn{2}{|c|}{ Open reading frame } \\
\hline & & & Hydro & HSP70 \\
\hline \multicolumn{5}{|l|}{ Ampelovirus } \\
\hline PMWaV-1 & AF414119 & $63.9(70.6)$ & $72.5(82.4)$ & $79.2(84.7)$ \\
\hline PMWaV-2 & AF283103 & $30.4(38.1)$ & $12.8(31.9)$ & $44.0(51.0)$ \\
\hline GLRaV-1 Czech & AY644650 & & & $34.4(41.4)$ \\
\hline GLRaV-1 & Y15891 & & & $34.6(42.6)$ \\
\hline GLRaV-1 Austria & AJ404738 & & & $35.8(43.6)$ \\
\hline GLRaV-1 Australia & AF195822 & $34.5(45.4)$ & $15.7(23.5)$ & $37.3(45.8)$ \\
\hline GLRaV-3 NY1 & NC004667 & $37.6(47.1)$ & $25.6(39.5)$ & $43.1(52.3)$ \\
\hline GLRaV-3 Brazil & AF438411 & $34.6(46.2)$ & & \\
\hline \multirow[t]{2}{*}{ GLRaV-3 Czech } & AY424408 & & & $41.4(50.8)$ \\
\hline & AY424407 & $24.5(32.7)$ & & \\
\hline GLRaV-3 China & AY495340 & $33.3(33.3)$ & & $37.3(47.5)$ \\
\hline GLRaV-3 Jordon & AY628766 & $34.6(46.2)$ & & \\
\hline GLRaV-5 & AF233934 & & & $63.8(73.4)$ \\
\hline GLRaV-5 Californian & AF039552 & & & $62.8(73.0)$ \\
\hline $\mathrm{LChV}-2$ & NC001598 & $33.7(47.7)$ & $17.8(50.0)$ & $39.6(46.0)$ \\
\hline LCV-2USA6b & AF531505 & $32.2(45.0)$ & $16.3(34.7)$ & $43.3(50.7)$ \\
\hline LChV-2 & AF295922 & $35.2(46.9)$ & & \\
\hline LChV-2 & AF416335 & $33.9(45.6)$ & $22.4(40.8)$ & $41.6(49.5)$ \\
\hline LChV-2 & AF333237 & $35.7(45.5)$ & & \\
\hline \multicolumn{5}{|l|}{ Tentative ampeloviruses } \\
\hline GLRaV-4 California & AF039553 & & & $65.0(75.1)$ \\
\hline GLRaV-6 Grecian & AJ496796 & & & $66.5(73.3)$ \\
\hline PBNSPaV & AF195501 & & & $46.0(55.6)$ \\
\hline \multicolumn{5}{|l|}{ Crinivirus } \\
\hline \multirow[t]{2}{*}{ LIYV } & U15440 & $32.9(44.9)$ & & \\
\hline & U15441 & & & $29.8(37.4)$ \\
\hline \multicolumn{5}{|l|}{ Closterovirus } \\
\hline BYV4 & AF190581 & $33.1(42.7)$ & $18.8(35.3)$ & $38.7(43.7)$ \\
\hline BYV Californian & AF056575 & $29.8(40.3)$ & $25.0(33.3)$ & $38.7(43.7)$ \\
\hline BYV Ukrainian & X73476 & $33.1(42.0)$ & $29.8(36.2)$ & $39.7(44.2)$ \\
\hline CTV T30 & AF260651 & $32.4(44.7)$ & $22.9(41.7)$ & $35.0(45.7)$ \\
\hline CTV VT & U56902 & $33.0(44.7)$ & $25.0(43.8)$ & $35.5(45.7)$ \\
\hline CTV T36 & U16304 & $30.6(42.2)$ & $22.9(41.7)$ & $35.2(46.4)$ \\
\hline GLRaV-2 Italy & Y14131 & $34.8(45.8)$ & $28.5(49.0)$ & $37.4(44.4)$ \\
\hline GLRaV-2 & AF039204 & $35.5(46.5)$ & $28.6(49.0)$ & $37.9(44.4)$ \\
\hline GLRaV-2 NZ & AY456132 & & $20.0(36.0)$ & $36.4(43.4)$ \\
\hline \multicolumn{5}{|c|}{ Unassigned in Closteroviridae family } \\
\hline GLRaV-7 VAA42 & Y15987 & & & $35.3(43.9)$ \\
\hline GLRaV-9 Californian & AY072797 & & & $66.3(74.8)$ \\
\hline LChV-1 & Y10237 & $30.0(42.9)$ & $23.3(33.3)$ & $32.8(42.1)$ \\
\hline OLYaV & Y18128 & & & $31.4(39.7)$ \\
\hline OLYaV Sicilian & AJ440010 & $32.6(46.6)$ & $22.7(38.6)$ & $31.5(40.5)$ \\
\hline
\end{tabular}

a PMWaV = Pineapple mealybug wilt associated virus; GLRaV = Grapevine leafroll associated virus; $\mathrm{LChV}=$ Little cherry virus; $\mathrm{PBNSPaV}=$ Plum bark necrosis and stem pitting associated virus; OLYaV = Olive leaf yellows associated virus; LIYV = Lettuce infectious yellows virus; BYV = Beet yellows virus; CTV = Citrus tristeza virus. Strains or sources follow virus acronym if known. were designed to produce a 495-bp amplicon (Fig. 1) spanning a portion of the HSP70 homolog region of PMWaV-3. This oligonucleotide pair did not produce amplicons of this size from pineapple accessions $45,158,109$, and 155 (Table 2) that were infected with PMWaV-1, PMWaV-2, dual infections of PMWaV-1 and -2 , or were PMWaV-free, respectively (Fig. 1, bottom row, lanes $3,4,5$, and 6 , respectively). Amplicons of the expected sizes were produced when primer pairs $225 / 226$, 223/224, and 263/264, specific for PMWaV-1, PMWaV-2, and PMWaV-3, respectively, were used in separate RTPCR assays on RNA from plants infected with all three PMWaVs (Fig. 2). Sequencing of selected amplicons showed that the primer pairs were detecting the expected PMWaV and were not detecting the other PMWaVs present. These RT-PCR assays were used to screen 38 USDA-ARS NCGR pineapple accessions (Table 2) and commercially grown, proprietary pineapple from six Smooth Cayenne cultivar selections and six hybrids, including a hybrid recently introduced to Hawaii from two different sources, Costa Rica (CR) and the Philippines (P) (Table 3). PMWaV-3 infections were detected in 23/38 NCGR accessions comprised of several different Ananas species and in several of the Hawaiian-grown hybrids but not in the traditionally grown 'Smooth Cayenne' selections (Tables 2 and 3).

Putative deletion mutant. A 396-bp amplicon was produced from pineapple accession no. 46 maintained at the USDAARS NCGR using primers 223 and 224, specific for PMWaV-2. This pineapple accession, designated 'Sugarloaf', originated from Zaire. Sequence analysis of the first $189 \mathrm{bp}$ of the putative deletion mutant PCR product showed $98.4 \%$ amino acid

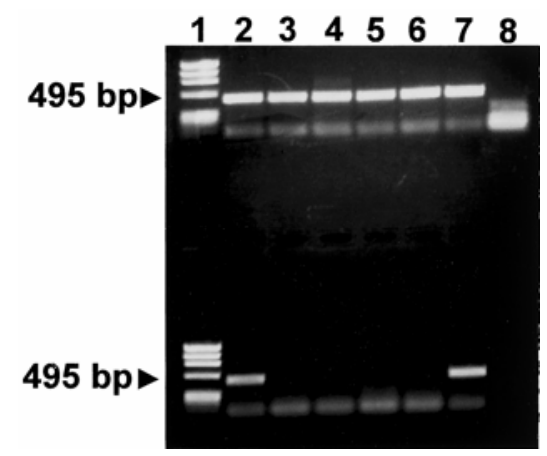

Fig. 1. Detection of Pineapple mealybug wilt associated virus-3 (PMWaV-3) using PMWaV3 -specific primers 263 and 264 in reverse transcription-polymerase chain reaction assays with RNA purified from several pineapple accessions maintained at the USDA-ARS National Germplasm Repository in Hilo, HI, that are shown in Table 2. Upper row, lane 1, PhiX174/HaeIII digest marker; lanes 2 to 8 , accessions 11,30 , $38,72,74,83,124$; lower row, lane 1 PhiX174/HaeIII digest marker; lanes 2 to 8 , accessions $160,45,158,109,155,160$, water control. 
identity to nucleotides 228 to 416 within the HSP70 homolog region of PMWaV-2, GenBank accession AF283103. The remaining 210 bp shared $95.7 \%$ amino acid identity with PMWaV-2, accession AF283103, from nucleotides 625 to 834 in the HSP70 homolog region. This deletion mutant lacks 207 bp spanning nucleotides 417 to 624 in the HSP70 region of PMWaV-2. The plant from which this deletion mutant was amplified was also inadditional genomic walking. The deletion mutant was repeatedly detected for over a 1-year period. The deletion mutant has not fected with PMWaV-2, which complicates

been detected in other pineapple accessions or in commercially grown 'Smooth Cayenne' selections.

Transmission and MWP symptom induction. PMWaV-3 can be acquired and transmitted by $D$. brevipes and $D$. neobrevipes mealybugs with or without the presence of PMWaV-1 or PMWaV-2 (Table 4). PMWaV-specific RT-PCR assays for all of the known PMWaVs present in the acquisition sources were used to screen the transmission test plants. Infections in $19 / 40$ viruliferous mealybug exposed test plants at 30 days post-IA (first screening), and in $34 / 40$ viruliferous mealybug ex-

Table 2. Pineapple mealybug wilt associated virus-1 (PMWaV-1), PMWaV-2, and PMWaV-3 infection-status of various pineapple accessions maintained at the USDA-ARS National Clonal Germplasm Repository in Hilo, HI

\begin{tabular}{|c|c|c|c|c|c|}
\hline No. $^{a}$ & Name $^{b}$ & $\begin{array}{l}\text { Geographic } \\
\text { origin }\end{array}$ & PMWaV-1 ${ }^{c}$ & PMWaV-2d & PMWaV-3e \\
\hline 11 & Columbia variety \#1 & USA & + & - & + \\
\hline 30 & 'Sylhet Jaldubi' & Philippines & - & - & + \\
\hline 38 & Wild Brazil, F $198^{\mathrm{f}}$ & Brazil & - & - & + \\
\hline 45 & 'NEP' & Vietnam & + & - & - \\
\hline 46 & 'Sugarloaf' & Zaire & - & + & + \\
\hline 50 & 'Bogota' & Columbia & - & - & + \\
\hline 59 & $\begin{array}{l}\text { F1 Cayenne } \times \\
\text { P. sagenarius }\end{array}$ & USA & - & - & - \\
\hline 63 & CB 2, Curawa ${ }^{\mathrm{h}}$ & Brazil & - & - & + \\
\hline 65 & $\mathrm{CB} 6^{\mathrm{f}}$ & Brazil & - & - & - \\
\hline 68 & $\mathrm{CB} 11^{\mathrm{i}}$ & Brazil & - & - & - \\
\hline 70 & $\mathrm{CB} 17^{\mathrm{j}}$ & Paraguay & - & - & - \\
\hline 72 & CB $19^{f}$ & Paraguay & - & - & + \\
\hline 73 & CB $20^{\mathrm{j}}$ & Paraguay & - & - & - \\
\hline 74 & $\mathrm{CB} 21^{\mathrm{k}}$ & Paraguay & - & - & + \\
\hline 75 & $\mathrm{CB} 23^{\mathrm{i}}$ & Argentina & - & - & + \\
\hline 83 & $\mathrm{CB} 61^{\mathrm{f}}$ & Brazil & - & - & + \\
\hline 88 & $\mathrm{CB} 71^{1}$ & Brazil & - & - & - \\
\hline 90 & 'Prazeres' & Brazil & - & - & - \\
\hline 100 & Cayenne $594 \mathrm{~N}$ & USA & + & - & + \\
\hline 109 & Cayenne Flowering Beauty & USA & + & + & - \\
\hline 111 & Cayenne M 111 seedy fruit & USA & - & + & + \\
\hline 121 & 'Amarillo' & Brazil & - & - & - \\
\hline 124 & 'Taboga' & Panama & - & - & + \\
\hline 126 & 'Smooth Anpi' & Taiwan & - & + & + \\
\hline 127 & ‘Kohi’ & Taiwan & - & - & - \\
\hline 129 & 'Philippine Green’ & Philippines & - & + & + \\
\hline 146 & 'Antigua' & Guatemala & - & - & - \\
\hline 148 & CB 24 & Paraguay & - & - & + \\
\hline 149 & CB 33 & Brazil & - & - & + \\
\hline 155 & Unnamed & USA & - & - & - \\
\hline 156 & $58-696$ & USA & - & - & - \\
\hline 157 & $63-759$ & USA & - & - & + \\
\hline 158 & $57-503$ & USA & - & + & - \\
\hline 159 & $58-1184$ & USA & - & - & + \\
\hline 160 & $53-116$ & USA & - & - & + \\
\hline 161 & $58-474$ & USA & - & - & + \\
\hline 162 & Cayenne John Teves & USA & - & - & + \\
\hline 163 & N91-05 & Thailand & + & + & + \\
\hline
\end{tabular}

${ }^{a}$ USDA-ARS National Clonal Germplasm Repository accession number.

b Varietal, cultivar, or other identifying name; all are Ananas comosus unless footnoted.

${ }^{c}$ PMWaV-1 was detected with PMWaV-1-specific primers in reverse transcription-polymerase chain reaction (RT-PCR) and PMWaV-1-specific MAb 35-6-5 using tissue blot immunoassay.

${ }^{d}$ PMWaV-2 was detected with PMWaV-2-specific primers in RT-PCR and PMWaV-2-specific MAb 63-2-2 using tissue blot immunoassay.

e PMWaV-3 was detected with PMWaV-3-specific primers in RT-PCR.

${ }^{\mathrm{f}}$ A. ananassoides.

${ }^{\mathrm{g}}$ Ananus sp.

h A. erectifolius.

i A. bracteatus.

${ }^{j}$ A. bracteatus var. rudis.

${ }^{\mathrm{k}}$ A. bracteatus var. tricolor.

${ }^{1}$ A. nanus. posed test plants by 70 days post-IA (second screening) were detected in plants exposed to viruliferous $D$. brevipes. No additional PMWaV infections were detected in the remaining six viruliferous mealybug exposed plants during the next 5 months of the experiment. Results with PMWaV-1- and PMWaV-2-specific TBIAs performed at 30 and 60 days postIA were identical to the RT-PCR results for the two viruses. The virus transmission rate to 'Smooth Cayenne' selection 2 with $D$. brevipes was lower than the transmission rate to hybrid $5(P<0.001 ; 1$-tailed paired $t$ test). PMWaVs transmitted by $D$. neobrevipes mealybugs were detected in $29 / 40$ viruliferous mealybug inoculated test plants 30 days post-IA (first sampling date) and in the remaining 11 test plants 60 days post-IA. There were no differences in virus transmission rates to 'Smooth Cayenne' selection 2 or hybrid 5 by viruliferous $D$. neobrevipes. None of the PMWaV-3-infected plants that were exposed to continuous $D$. brevipes or $D$. neobrevipes mealybug feeding developed typical MWP symptoms unless infected with PMWaV-2 (Table 4). If PMWaV-2 was present, plants developed symptoms of MWP including severe tip dieback, which moved down the leaf in an inverted "V" pattern, downward curling of the leaf margins, and red mottling of leaves 45 to 95 days after mealybug exposure began. A white margin along the downwardcurled leaf margin and between the dying tip and the reddening apical portion of the leaves was often observed in the plants of selection 2 but not in hybrid 5 plants, which typically exhibit higher levels of anthocyanin than selection 2. Symptom induction was delayed several weeks in four plants in the $D$. brevipes test group

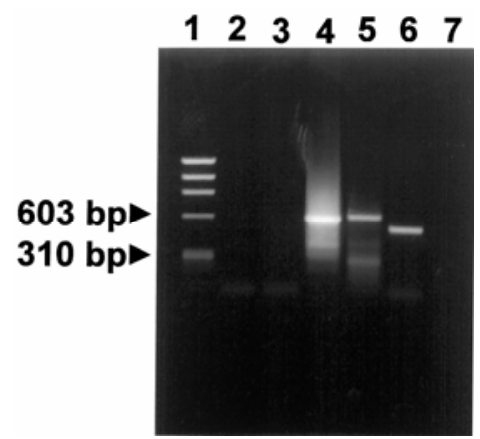

Fig. 2. Detection and differentiation of Pineapple mealybug wilt associated virus-1 (PMWaV1), PMWaV-2, and PMWaV-3 from a plant infected with all three PMWaVs using three pairs of PMWaV-specific oligonucleotides in reverse transcription-polymerase chain reaction assays. Lane 1, PhiX174/HaeIII digest marker; lane 2, water control with primers 223 and 224; lane 3, water control with primers 225 and 226; lane 4, PMWaV-1-infected plant (primers 225 and 226); lane 5, PMWaV-2-infected plant (primers 223 and 224); lane 6, PMWaV-3infected plant (primers 263 and 264); lane 7 water control with primers 263 and 264. 
(Table 4). All plants exposed to D. neobrevipes mealybugs regardless of virus exposure developed many 2- to 7-mm dark green areas visible on the adaxial sides of the leaves, which were associated with feeding sites of the mealybugs and not MWP. Test plants continually exposed only to mealybugs given acquisition to leaves of plants without PMWaV-1, PMWaV-2, and PMWaV-3 remained free of these viruses and did not develop symptoms of MWP. Plants infected with combinations of any of the three PMWaVs did not develop MWP if maintained mealybug-free after initial IA.

TBIAs with PMWaV-1- and PMWaV2-specific MAbs showed that PMWaV-3 was not detected by two MAbs, 35-6-5 and 63-1-2, for PMWaV-1 or two MAbs, 30 and 63-2-2, for PMWaV-2 (Table 2). ISEM analysis of virus preparations made from plants infected with PMWaV-1- and PMWaV-3-infected plants showed MAb 35-6-5 decoration of approximately 40 to $60 \%$ of the particles. No decoration was observed with MAb 63-2-2. Analyses of virus preparations isolated from plants containing both PMWaV-2 and PMWaV-3 showed labeling of approximately $50 \%$ of the particles with specific MAb 63-2-2 for PMWaV-2 and no decoration with MAbs 35-6-5 and 63-1-2. Purified preparations of PMWaV-3 only were not decorated by MAbs 63-2-2 or 35-3-5.

Table 3. Incidences ${ }^{\mathrm{a}}$ of Pineapple mealybug wilt associated virus-1 (PMWaV-1), PMWaV-2, and PMWaV-3 in plants from various commercially grown Ananas comosus cultivar selections and hybrids in Hawaii

\begin{tabular}{lcccccc}
\hline \multirow{2}{*}{$\begin{array}{l}\text { Pineapple } \\
\text { clone }\end{array}$} & $\mathbf{1}$ only & $\mathbf{2}$ only & $\mathbf{3}$ only & $\mathbf{1}$ and 3 & $\mathbf{2}$ and 3 & $\mathbf{1 , 2}$, and 3 \\
\hline & $28 \pm 4$ & $1 \pm 1$ & 0 & 0 & 0 & 0 \\
Selection 1 & $28 \pm 4$ & $19 \pm 3$ & 0 & 0 & 0 & 0 \\
Selection 2 & $45 \pm 7$ & $2 \pm 1$ & 0 & 0 & 0 & 0 \\
Selection 3 & $82 \pm 5$ & $1 \pm 1$ & 0 & 0 & 0 & 0 \\
Selection 4 & $99 \pm 1$ & 0 & 0 & 0 & 0 & 0 \\
Selection 5 & $43 \pm 7$ & $<1 \pm 1$ & 0 & 0 & 0 & 0 \\
Selection 6 & $12 \pm 5$ & $9 \pm 7$ & 0 & $<1 \pm 1$ & 0 & 0 \\
Hybrid 4 & $16 \pm 10$ & $5 \pm 4$ & 0 & $5 \pm 3$ & $2 \pm 1$ & 0 \\
Hybrid 5 & 0 & 0 & 0 & $2 \pm 1$ & 0 & 0 \\
Hybrid 6 & $<1 \pm 1$ & $<1 \pm 1$ & 0 & 0 & 0 & 0 \\
Hybrid 7 & 0 & 0 & 0 & 0 & 0 & 0 \\
Hybrid 8 & $31 \pm 7$ & $5 \pm 2$ & $9 \pm 1$ & $3 \pm 3$ & $5 \pm 1$ & $5 \pm 1$ \\
Hybrid 9 CR & 0 & 0 & 0 & 0 & 0 & 0 \\
Hybrid 9 P & 0 &
\end{tabular}

${ }^{\mathrm{a}}$ Incidences reflect the percentage of plants infected with PMWaV-1, PMWaV-2, PMWaV-3, or combinations of the viruses. Incidences are based on detection results using PMWaV-1- and PMWaV-2specific tissue blot assays and reverse transcription-polymerase chain reaction (RT-PCR) assays specific for PMWaV-1, PMWaV-2, and PMWaV-3. Mean incidences and standard errors for cultivar selections were derived from 5 independent samples of 25 randomly selected plants from each cultivar selection or 20 randomly selected plants from each hybrid.

Table 4. Transmission of Pineapple mealybug wilt associated virus-1 (PMWaV-1), PMWaV-2, and PMWaV-3 by Dysmicoccus brevipes or D. neobrevipes mealybugs and the induction of mealybug wilt of pineapple (MWP) symptoms

\begin{tabular}{|c|c|c|c|c|c|}
\hline \multirow{2}{*}{$\begin{array}{l}\text { Mealybug sp. } \\
\text { acquisition source }\end{array}$} & \multirow{2}{*}{$\begin{array}{c}\text { Virus } \\
\text { combination }\end{array}$} & \multicolumn{2}{|c|}{ Infection incidence ${ }^{a}$} & \multicolumn{2}{|c|}{ Symptom incidence $e^{b}$} \\
\hline & & S2 & H5 & S2 & H5 \\
\hline \multicolumn{6}{|l|}{ D. brevipes } \\
\hline 100 & 1 and 3 & $4 / 5$ & $5 / 5$ & $0 / 5$ & $0 / 5$ \\
\hline 111 & 2 and 3 & $4 / 5$ & $5 / 5$ & $4^{c} / 5$ & $5 / 5$ \\
\hline 126 & 2 and 3 & $3 / 5$ & $4 / 5$ & $3^{\mathrm{d} / 5}$ & $4 \% / 5$ \\
\hline H9 & 3 & $4 / 5$ & $5 / 5$ & $0 / 5$ & $0 / 5$ \\
\hline Selection 1 & - & $0 / 5$ & $0 / 5$ & $0 / 5$ & $0 / 5$ \\
\hline \multicolumn{6}{|l|}{ D. neobrevipes } \\
\hline 100 & 1 and 3 & $5 / 5$ & $5 / 5$ & $0 / 5$ & $0 / 5$ \\
\hline 111 & 2 and 3 & $5 / 5$ & $5 / 5$ & $5 / 5$ & $5 / 5$ \\
\hline 126 & 2 and 3 & $5 / 5$ & $5 / 5$ & $5 / 5$ & $5 / 5$ \\
\hline $\mathrm{H} 9$ & 3 & $5 / 5$ & $5 / 5$ & $0 / 5$ & $0 / 5$ \\
\hline Selection 1 & - & $0 / 5$ & $0 / 5$ & $0 / 5$ & $0 / 5$ \\
\hline
\end{tabular}

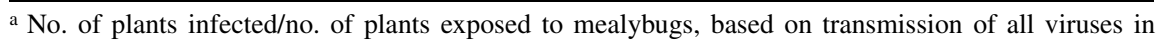
acquisition source using Dysmicoccus brevipes or D. neobrevipes as noted.

${ }^{b}$ MWP symptoms consisted of red mottling of the leaves, severe tip dieback that moved down the leaves in an inverted "V" formation, and downward curling of the leaf tips and margins. Symptoms in selection 2 often included a white margin between the dead leaf tip and the reddening of the apical portion of the leaves. The white margin was absent in H5.

${ }^{c}$ One plant did not develop typical MWP symptoms until 140 days after inoculation access (IA).

${ }^{d}$ Two plants did not develop typical MWP symptoms until 120 and 160 days after IA. Neither plant developed a white margin between the dying leaf tips and the reddening of the apical portion of the leaf or along the leaf margin.

e One plant did not develop typical MWP symptoms until 130 days after IA.

\section{DISCUSSION}

The use of degenerate oligonucleotides based on conserved sequences of related viruses in RT-PCR has proven to be a valuable tool for identifying the existing diversity within virus species and complexes for the last decade $(5,10)$. This relatively rapid type of detection can be extremely valuable in assisting the practical application of pathogen screening and eradication efforts associated with maintaining clean or certified germ plasm and propagation materials. We report here the identification of putative PMWaV-3 in pineapples using this type of screening. Sequence analyses of the C-terminal portion of the RdRp, the complete ORF for a small hydrophobic protein, and the $\mathrm{N}$ terminal portion of the HSP70-like ORF suggest putative PMWaV-3 is a distinct virus and not a strain of the previously characterized PMWaV-1. PMWaV-3 and the tentative ampeloviruses GLRaV-4 and GLRaV-6, and GLRaV-9, an unassigned member of the family Closteroviridae, share 73.3 to $75.1 \%$ amino acid similarity, suggesting that these viruses are more closely related than PMWaV-3 is with other ampeloviruses such as PMWaV-2, GLRaV-1, and GLRaV-3, and the Closterovirus GLRaV-2.

Previously, four different MAbs capable of detecting various coat protein surface epitopes present on PMWaV-1 or PMWaV-2 were produced for use in TBIAs. These specific assays have been used to screen over 100,000 plants and propagules. These antibodies, however, do not show antigenicity to putative PMWaV-3 particles; thus, production of specific monoclonal antibodies capable of detecting additional PMWaVs viruses in TBIAs would be extremely valuable for mass virus screening tasks.

The diversity that is being identified in the citrus tristeza, grapevine leafroll, and now pineapple mealybug wilt disease complexes poses a challenge to researchers to not only develop broad spectrum crop protection strategies but also to develop broad spectrum detection assays that can identify a potentially diverse group of related pathogens that may occupy overlapping but not identical niches. Several proprietary pineapple hybrids are currently being expanded in Hawaii and will eventually replace the more traditional 'Smooth Cayenne' selections that have been grown for almost a century in Hawaii. The expansion of these hybrids provides an opportunity for the commercial pineapple plantations in Hawaii to replace the commercial selections that had relatively high (20 to $100 \%$ ) incidences of PMWaV-1 and PMWaV-2 with planting material that has not had the years of exposure to viruliferous mealybugs. Unfortunately, this study has shown that many of the relatively new hybrids have already been exposed to PMWaVs, and incidences of PMWaV-1, PMWaV-2, and PMWaV-3 vary from $0 \%$ 
to nearly $50 \%$ in a hybrid recently imported into Hawaii from Costa Rica. Other than pineapple, no alternative hosts of the PMWaVs have been reported. Thus, new infections arise from systemically infected planting material or by mealybugs acquiring the virus from infected pineapple plants and moving or being blown onto other pineapple. Eradication of the viruses by planting only PMWaV-free material is a possible management strategy. However, pineapple is typically planted at densities of 60,000 to 90,000 plants per hectare. If companies are to invest in a mass screening methodology for the PMWaVs, then it is vital that assays for a potentially wide diversity of PMWaVs be developed to increase the chances of obtaining clean material. The Hawaiian pineapple plantations need to decide on an individual basis whether the potentially long-term economical advantage of growing PMWaVfree pineapple material is worth the extra labor investment involved in reducing and eventually eradicating PMWaVs in the relatively new hybrids currently under expansion.

PMWaV-3 can be transmitted by $D$. brevipes and $D$. neobrevipes in the absence or presence of PMWaV-1 or PMWaV-2. In this transmission study, D. brevipes mealybugs had reduced transmission efficiency. Whether or not the reduced efficiency is due to physiological or behavioral characteristics of the vector is currently unknown. Transfer of the acquisition material containing actively feeding $D$. brevipes mealybugs was made directly to the central whorl of youngest leaves arising from the apical meristem area. Under typical field conditions in Hawaii, pink pineapple mealybugs are typically found feeding on the basal portions of the oldest living leaves arising from the base of the pineapple stem or on the adventitious roots. During fruit production, pink pineapple mealybugs are occasionally found feeding on the base of the fruit. It is possible that in the small-scale experiments conducted in this study, the pink pineapple mealybugs inoculated to 2- to 3month-old plants sought out cryptic places such as roots or base of the plant before reestablishing the feeding process. This delay in re-establishing feeding could potentially impact the rate of semipersistent transmission and establishment of viral infections. The lower transmission efficiency of $D$. brevipes was also more pronounced with the Smooth Cayenne cultivar than with the more succulent leafed hybrid 5. The cryptic feeding locations of D. brevipes mealybugs typically reduce the impact of foliar-applied insecticides, such as diazinon, in controlling this particular vector of the PMWaVs on the commercial plantations. Thus, although $D$. brevipes mealybugs had a slightly lower transmission rate in these studies, their cryptic nature complicates detection and control measures, rendering this insect a major pest in pineapple. Alternatively, D. neobrevipes mealybugs, which had higher transmission efficiencies, favor the upper leaf portion of a pineapple plant. These vectors may have left the acquisition source which was placed in the leaf whorl and established feeding on nearby leaves more rapidly than did the pink pineapple mealybugs. This selection of feeding location, however, renders gray pineapple mealybugs more susceptible to foliar application of diazinon. This vector species also leaves a characteristic spotting on the leaves, making detection more straightforward. Regardless of whether the slight differences in transmission efficiency are due to behavior or physiology, both mealybug species are a serious threat to maintaining PMWaV-free pineapple. The expected loss of diazinon for pineapple in the next 2 years leaves the industry with no simple chemical options.

PMWaV-3 infection in the presence of $D$. brevipes or $D$. neobrevipes mealybugs did not result in symptom induction of MWP if PMWaV-2 was absent. MWP symptoms were only induced in mealybugexposed plants and only if PMWaV-2 was present, suggesting that $\mathrm{PMWaV-3}$ is not involved in the induction of MWP and supporting our previous work showing PMWaV-2 and mealybugs play a role in the etiology of MWP $(24,25)$. Also of importance is that both species of mealybugs tested here had the ability to induce MWP if PMWaV-2 was present. PMWaV-3 shares the highest homology with PMWaV-1. Plants infected with PMWaV1, like PMWaV-3, do not develop MWP symptoms if exposed to mealybugs in the absence of PMWaV-2 (24,25). Our previous research has focused on the introduction of various PMWaVs using mealybugs and their correlation with induction of MWP symptoms. However, disease severity, recovery, length of latent period until symptom expression, or changes in specific transmission parameters when combinations of viruses are used, have not been thoroughly evaluated. Temperature, day length, and light conditions, nutrient conditions, cultivar or hybrid, water availability, and other factors also influence the onset and degree of MWP severity and symptom expression, and may also influence the roles of the PMWaVs in pineapple disease. Different grapevine leafroll disease phenotypes have been observed depending on which GLRaVs are present. Thus, although PMWaV-1 and PMWaV-3 do not appear to be involved in the induction of MWP symptoms in the presence of mealybugs, their association with mealybugs and often with diseased plants requires further evaluation before reclassifying these mealybug wilt associated viruses as "not mealybug wilt associated". The development of degenerate- and specificprimer based RT-PCR assays for the
PMWaVs provides the necessary tools for identifying PMWaV-free plant material that can be used to evaluate whether or not PMWaV-1, PMWaV-3, and possibly other ampeloviruses are indeed associated with MWP.

PMWaV-1 infection has been correlated with reductions in pineapple fruit yield in the ratoon crop of two different commercial proprietary selections $(23-25,28)$. Thus, it is possible that PMWaV-3 infections may have similar deleterious effects on growth rate or pineapple fruit yield. We have previously shown that PMWaV-1 can be eliminated through apical or meristematic bud propagation (26). This enables the NCGR to potentially obtain PMWaVfree material from the infected crowns and prevent the spread of the PMWaVs. Mealybug transmissibility of the PMWaVs, the involvement of PMWaV-2 in MWP, and the growth impacts of PMWaV-1 and PMWaV-2 should make elimination of PMWaVs an important focus for pineapple growers worldwide.

\section{ACKNOWLEDGMENTS}

This research was funded, in part, by grants from the Hawaii Department of Agriculture agreement numbers 2002-34135-12724 and 2003-3413513982, and by the specific Cooperative Grant agreement 58-5320-5-604 between the USDA-ARS and the University of Hawaii. We thank W. Borth and D. Gaskill for providing comments and suggestions regarding this manuscript. This is Journal Series No. 4696 of the College of Tropical Agriculture and Human Resources.

\section{LITERATURE CITED}

1. Carter, W. 1933. The pineapple mealy bug, Pseudococcus brevipes, and wilt of pineapples. Phytopathology 23:207-242.

2. Carter, W. 1942. Geographic distribution of mealybug wilt with some other insect pests of pineapple. J. Econ. Entomol. 35:10-15.

3. Carter, W. 1963. Mealybug wilt of pineapple; a reappraisal. Ann. N.Y. Acad. Sci. 105:741-764.

4. Gunasinghe, U. B., and German, T. L. 1989 Purification and partial characterization of a virus from pineapple. Phytopathology 79: 1337-1341.

5. Hilf, M. E., Karasev, A. V., Albiach-Marti, M. R., Dawson, W. O., and Garnsey, S. M. 1999. Two paths of sequence divergence in the citrus tristeza virus complex. Phytopathology 89: 336-342.

6. Hu, J. S., Gonsalves, A., Sether, D., and Ullman, D. E. 1993. Detection of pineapple closterovirus, a possible cause of mealybug wilt of pineapple. Acta Hortic. 334:411-416.

7. Hu, J. S., and Sether, D. M. 1999. Etiology of mealybug wilt of pineapple. Page 321 in: Abstr. Int. Congr. Virol. Xth. Sydney, Australia.

8. Hu, J. S., Sether, D. M., Liu, X. P., Wang, M., Zee, F., and Ullman, D. E. 1997. Use of a tissue blotting immunoassay to examine the distribution of pineapple closterovirus in Hawaii. Plant Dis. 81:1150-1154.

9. Hu, J. S., Sether, D. M., and Ullman, D. E. 1996. Detection of pineapple closterovirus in pineapple plants and mealybugs using monoclonal antibodies. Plant Pathol. 45:829-836.

10. Karasev, A. 2000. Genetic diversity and evolution of closteroviruses. Annu. Rev. Phytopathol. 38:293-324.

11. Krauss, B. 1948. Anatomy of the vegetative organs of the pineapple, Ananas comosus (L.) Merr. Bot. Rev. 110:159-217. 
12. Ling, K.-S., Zhu, H.-Y., Drong, R. F., Slightom, J. L., McFerson, J. R., and Gonsalves, D. 1998. Nucleotide sequence of the 3'terminal two-thirds of the grapevine leafrollassociated virus-3 genome reveals a typical monopartite closterovirus. J. Gen. Virol. 79:1299-1307.

13. Martelli, G. P., Agranovsky, A. A., Bar-Joseph, M., Boscia, D., Candressa, T., Coutts, R. H. A., Dolja, V. V., Falk, B. W., Gonsalves, D., Jelkmann, W., Karasev, A. V., Miafra, A., Namba, S., Vetten, H. J., Wisler, G. C., and Yoshikawa, N. 2002. The family Closteroviridae revised. Arch. Virol. 147:2039-2044.

14. Mawassi, M., Mietkiewska, E., Gofman, R., Yang, G., and Bar-Joseph, M. 1996. Unusual sequence relationships between two isolates of citrus tristeza virus. J. Gen. Virol. 77:23592364.

15. Melzer, M. J., Karasev, A. V., Sether, D. M., and $\mathrm{Hu}$, J. S. 2001. Nucleotide sequence, genome organization, and phylogenetic analysis of pineapple mealybug wilt-associated virus- 2 . J. Gen. Virol. 82:1-7.

16. Rohrbach, K. G. 1991. Pineapple: The plant and its culture. Hawaii Institute of Tropical Agriculture and Human Resources, University of Hawaii at Manoa. Hawaii Agric. Exp. Stn., Honolulu.

17. Rohrbach, K. G., and Apt, W. J. 1986. Nematode and disease problems of pineapple. Plant Dis. 70:81-87.
18. Rohrbach, K. G., Beardsley, J. W., German, T. L., Reimer, N. J., and Sanford, W. G. 1988. Mealybug wilt, mealybugs, and ants on pineapple. Plant Dis. 72:558-565.

19. Rubio, L., Soong, J., Kao, J., and Falk, B. W. 1999. Geographic distribution and molecular variation of isolates of three whitefly-borne closteroviruses of cucurbits: Lettuce infectious yellows virus, cucurbit yellow stunting disorder virus, and beet pseudo-yellows virus. Phytopathology 89:707-711.

20. Rubio, L., Tian, T., Yeh, H.-H., and Falk, B. W. 1999. Heterogeneous population of defective RNAs in plants infected with lettuce infectious yellows virus (LIYV). (Abstr.) Phytopathology 89:S67.

21. Sether, D. M., and Hu, J. S. 1999. Mealybugs and pineapple mealybug wilt associated virus are both necessary for mealybug wilt. (Abstr.) Phytopathology 89:S70.

22. Sether, D. M., and Hu, J. S. 2000. A closterovirus and mealybug exposure are both necessary components for mealybug wilt of pineapple symptom induction. (Abstr.) Phytopathology 90:S71.

23. Sether, D. M., and Hu, J. S. 2001. The impact of pineapple mealybug wilt-associated virus-1 and reduced irrigation on pineapple yield. Australas. Plant Pathol. 30:31-36.

24. Sether, D. M., and Hu, J. S. 2002. Closterovirus infection and mealybug exposure are necessary for the development of mealybug wilt of pineapple disease. Phytopathology 92:928935.

25. Sether, D. M., and Hu, J. S. 2002. Yield impact and spread of Pineapple mealybug wilt associated virus-2 and mealybug wilt of pineapple in Hawaii. Plant Dis. 86:867-874.

26. Sether, D. M., Karasev, A. V., Okumura, C., Arakawa, C., Zee, F., Kislan, M. M., Busto, J. L., and Hu, J. S. 2001. Differentiation, distribution, and elimination of two different Pineapple mealybug wilt-associated viruses found in pineapple. Plant Dis. 85:856-864

27. Sether, D. M., Ullman, D. E., and Hu, J. S 1998. Transmission of pineapple mealybug wilt-associated virus by two species of mealybug (Dysmicoccus spp.). Phytopathology 88:1224-1230.

28. Sipes, B. S., Sether, D. M., and Hu, J. S. 2002 Interactions between Rotylenchus reniformis and Pineapple mealybug wilt associated virus1 in pineapple. Plant Dis. 86:933-938.

29. Williams, D. J., and Watson, G. W. 1988. The Scale Insects of the Tropical South Pacific Region, Part 2. The Mealybugs (Pseudococcidae) $\mathrm{CAB}$ International Institute of Entomology, London, England

30. Zhu, H. Y., Ling, K. S., Goszczynski, D. E., McFerson, J. R., and Gonsalves, D. 1998. Nucleotide sequence and genome organization of grapevine leafroll-associated virus- 2 are similar to beet yellows virus, the closterovirus type member. J. Gen. Virol. 79:1289-1298. 